\title{
REVIEW
}

\section{Heterotrophic dinoflagellates: a significant component of microzooplankton biomass and major grazers of diatoms in the sea}

\author{
Evelyn B. Sherr*, Barry F. Sherr \\ College of Oceanic and Atmospheric Sciences, Oregon State University, Corvallis, Oregon 97331-5503, USA
}

\begin{abstract}
This review summarizes evidence that heterotrophic (non-pigmented, phagotrophic) dinoflagellates are often a significant component of the biomass of phagotrophic protists in the microplankton size class (20 to $200 \mu \mathrm{m}$ ), and that heterotrophic dinoflagellates are likely to be more quantitatively significant consumers of bloom-forming diatoms than copepods and other mesozooplankton. Although it has been assumed that the microzooplankton community is usually dominated by ciliates, non-pigmented dinoflagellates, including both thecate (armored forms, e.g. Protoperidinium spp.) and athecate gymnodinoid species, frequently compose $>50 \%$ of microzooplankton biomass, and often occur at high abundance during diatom blooms. Since phagotrophic dinoflagellates appear able to grow on diverse prey taxa and to persist at low food abundance, these protists may be able to survive during non-bloom conditions and then grow up when phytoplankton blooms occur. Heterotrophic dinoflagellates are also likely to be an important food resource for mesozooplankton. Due to fundamental differences in growth and grazing rates between phagotrophic dinoflagellates and copepods, it is vital for accurate modeling of planktonic food webs to account for grazing by both of these groups of herbivores during diatom blooms.
\end{abstract}

KEY WORDS: Microzooplankton - Heterotrophic dinoflagellates · Herbivory . Diatoms . Phytoplankton blooms · Plankton

An association between diatom blooms and heterotrophic dinoflagellates has been noted in many environments. Feeding rate measurements have indicated that heterotrophic dinoflagellates may be significant consumers of diatom blooms.

Lessard (1991, p. 49)

\section{INTRODUCTION}

Since Landry \& Hassett (1982) first proposed the dilution method to quantify the rate of consumption of phytoplankton by microzooplankton (organisms $<200 \mu \mathrm{m}$ in size) the assay has been widely used in various regions of the world ocean. The resulting data sets have unequivocally demonstrated that in both eutrophic and oligotrophic pelagic systems, microzooplankton are quantitatively more significant grazers of phytoplankton biomass than mesozooplankton (organisms 200 to $2000 \mu \mathrm{m}$ in size, including copepods and other metazoan grazers) (Sherr \& Sherr 2002, Calbet \& Landry 2004).

Although this fact is by now well-established, misconceptions remain about the roles of microzooplanktonic protists in marine food webs; two of the most common and serious being that microzooplankters mainly consume small phytoplankton cells, while mesozooplankton are the dominant grazers of phytoplankton cells ca. $>20 \mu \mathrm{m}$ in size, and that microzoo- 
planktonic protists are mainly ciliates. As an example, in a recently published diagram of a generic pelagic food web (see Fig. 2 of Rothstein et al. 2006) no trophic link is shown between protists and large phytoplankton, and microzooplankton-sized protists are labeled 'ciliates.' It has long been tacitly assumed that the community of microzooplanktonic protists is usually dominated by ciliates in terms of numbers and biomass (Ducklow 1983, Sherr \& Sherr 1988, Pierce \& Turner 1995, Dolan et al. 2000, Perez et al. 2000, Dolan \& McKeon 2004, Vladstein et al. 2004). The group of non-ciliate protists most often recognized as potentially significant herbivores are phagotrophic nanoflagellates that consume $<5 \mu \mathrm{m}$-sized phytoplankton (Sherr \& Sherr 1992, Landry et al. 1995, Maixandeau et al. 2005).

Because ciliates and nanoflagellates are known to preferentially feed on cells of $<20 \mu \mathrm{m}$ (i.e. picoplankton and nanoplankton; Jonsson 1986, Fenchel 1987, Sherr \& Sherr 1992), the assumption that the microzooplankton is dominated by these protists has led to an apparently widely held idea in the marine science community that the generally important consumers of chain-forming and large diatoms are not herbivorous protists, but copepods and other mesozooplankton. This pervasive assumption underlies statements such as that in Barber \& Hiscock (2006, p. 10) regarding an iron enrichment-induced diatom bloom in the equatorial Pacific (italics added by us): ' ...which allows ambient diatom biomass to initially accumulate faster than ambient mesozooplankton can consume it (Landry et al. 2000),' even though what Landry et al. (2000) actually concluded was : 'The available data ...suggest that the accumulation of diatoms early in the bloom was as much a consequence of decreased microzooplankton grazing as increased diatom growth,' and '...we can surmise that the absence of a substantial mesozooplankton response to the patch bloom left a void that was filled by large, fast-growing protists capable of consuming and suppressing pennate diatoms.' Despite the findings of Landry et al. (2000), Barber \& Hiscock (2006) presented conceptual food web diagrams depicting copepods as sole grazers of larger diatoms, and microzooplankton as consumers of only picophytoplankton and smaller protists.

The failure to recognize heterotrophic dinoflagellates as significant grazers of bloom-forming diatoms in the sea is curious, for it is $16 \mathrm{yr}$ since this was first suggested by Lessard (1991). Furthermore, there have been subsequent studies demonstrating the presence of heterotrophic dinoflagellates during diatom blooms. Here, we summarize evidence showing that of the major groups of herbivores in pelagic systems, heterotrophic dinoflagellates have the greatest potential to consume large and chain forming diatoms. Ciliates typically feed selectively at a predator-prey size ratio of 10:1 (Jonsson 1986, Fenchel 1987), while heterotrophic dinoflagellates can consume prey cells as large as themselves, or even larger (Lessard 1991, Hansen 1992, Buck \& Newton 1995, Strom \& Strom 1996, Jeong 1999, Jeong et al. 2004, Horner et al. 2005, Saito et al. 2006).

The main objective of this review is to provide a clearer understanding of the contribution of heterotrophic dinoflagellates to microzooplankton stocks, and of their potential grazing impacts in the sea by (1) demonstrating that heterotrophic dinoflagellates can be a significant component of the biomass of phagotrophic protists in the microzooplankton size class, and (2) summarizing evidence suggesting that heterotrophic dinoflagellates can be as significant as mesozooplankton in consuming bloom-forming diatoms. In addition, laboratory studies suggest that heterotrophic dinoflagellates are relatively non-selective feeders, and may be able to persist at low food abundance. Hence, these protists may survive during non-bloom conditions either feeding on alternative prey, or simply enduring low prey abundances until phytoplankton blooms re-occur. With the abundance of food during blooms, rapid multiplication of dinoflagellate populations can resume.

Since bloom-forming diatoms are responsible for a large part of global new/export production in the sea (Sarthou et al. 2005, Barber \& Hiscock 2006), understanding the pathways of this production is of compelling interest. Although the primary fate of diatom biomass is mass sinking following bloom senescence (Smetacek 1985, Passow 1991, Turner 2002, Sarthou et al. 2005), the information summarized here suggests that the amount of bloom biomass consumed by heterotrophic dinoflagellates in the water column could be at least as great, if not greater, than that consumed by mesozooplankton. Since phagotrophic protists and copepods have fundamentally different growth and grazing responses to prey abundance, it is important to account for grazing by both of these groups of herbivores during diatom blooms.

It should be noted that many species of chloroplastbearing dinoflagellates are also capable of phagotrophy. For example, the phototrophic dinoflagellate Akashiwo snguinea (synonym: Gymnodinium sanguineum) was reported to consume spirotrichous ciliates (Bockstahler \& Coats 1993), the photosynthetic athecate dinoflagellate Gyrodinium instriatum was able to prey on tintinnid ciliates (Uchida et al. 1997), and the armored phototrophic dinoflagellate Fragilidium cf. mexicanum was observed feeding on red tide and toxic dinoflagellates (Jeong et al. 1999). However, in this review we focus specifically on non-pigmented species of dinoflagellates. 


\section{REVIEW}

\section{Heterotrophic dinoflagellates are a significant component of the microzooplankton}

Heterotrophic dinoflagellates have been recognized as ubiquitous in marine pelagic systems since Lessard \& Swift $(1985,1986)$ demonstrated that about half of dinoflagellate species in marine plankton did not have chloroplasts and consumed other plankton cells. Subsequent work has confirmed that heterotrophic dinoflagellates are common in marine pelagic systems and have a potentially important role as herbivores (Lessard 1991, Hansen 1992, Lessard \& Murrell 1996, Hansen \& Calado 1999, Jeong 1999, Jeong et al. 2004).

In assemblages of heterotrophic dinoflagellates in marine systems, athecate dinoflagellates are typically more abundant (in both numbers and biomass) than armored dinoflagellates, which have cellulosic thecal plates (e.g. citations in Table 1, and data presented in Fig. 1B). Athecate dinoflagellates include $<20 \mu \mathrm{m}$ sized species such as the 10-12 $\mu \mathrm{m}$ Gymnodinium sp. isolated from the subarctic Pacific (Strom 1991), similar to a species we observed in Georgia salt marsh estuaries (Sherr et al. 1991), and the 10-15 $\mu \mathrm{m}$ spindle-shaped dinoflagellates that are abundant during the North Atlantic spring bloom (Verity et al. 1993). Larger ( $>40 \mu \mathrm{m}$ in length) athecate, heterotrophic dinoflagellates (either spindle/fusiform species such as Gyrodinium spirale, or round/tear-drop-shaped Gyrodinium spp.; Fig. 2A-C) are common under eutrophic conditions (e.g. inshore or shallow coastal habitats), or are associated with diatom blooms in the open ocean.

The results of a number of studies of biomass stocks of heterotrophic protists in the microzooplankton size range are shown in Table 1 . In most of these studies, the communities of microzooplanktonic protists were categorized so that the proportional contribution of ciliates, thecate dinoflagellates and athecate dinoflagellates to total microzooplankton biomass may be determined. The results show that heterotrophic dinoflagellates often account for more than half of the total biomass of microzooplankton, although in winter and under non-bloom conditions heterotrophic dinoflagel-

Table 1. Mean \pm SD total microzooplankton (MZP) protist biomass (ciliates plus heterotrophic dinoflagellates) and total heterotrophic dinoflagellate (Hdino) biomass as percent of total MZP biomass in several marine systems. -: no data

\begin{tabular}{|c|c|c|c|c|}
\hline System & $\begin{array}{l}\text { MZP biomass } \\
\text { (range) }\end{array}$ & $\begin{array}{l}\text { Hdino \% } \\
\text { of total MZP } \\
\text { biomass }\end{array}$ & $\begin{array}{l}\text { Athecate Hdino \% } \\
\text { of total Hdino } \\
\text { biomass }\end{array}$ & Source \\
\hline $\begin{array}{l}\text { Western Arctic Ocean, } \\
\text { bloom and non-bloom }\end{array}$ & $\begin{array}{c}13 \pm 16 \mu \mathrm{g} \mathrm{C}^{-1} \\
(1.6-60)\end{array}$ & $60 \pm 20$ & $87 \pm 13$ & Sherr et al. (in press) \\
\hline Barents Sea & $\begin{array}{c}12.4 \pm 3.4 \mu \mathrm{g} \mathrm{Cl} \mathrm{l}^{-1} \\
(9-17)\end{array}$ & $55 \pm 14$ & - & Verity et al. (2002) \\
\hline $\begin{array}{l}\text { Disko Bay, Greenland, } \\
\text { April-October }\end{array}$ & $\begin{array}{c}330 \pm 240 \mathrm{mg} \mathrm{C} \mathrm{m} \mathrm{m}^{-2} \\
(130-760)\end{array}$ & $47 \pm 14$ & $90 \pm 5$ & Levinsen \& Nielsen (2002) \\
\hline $\begin{array}{l}\text { Southeast Bering Sea, } \\
\text { bloom and non-bloom }\end{array}$ & $\stackrel{-}{\left(9.5-133 \mu \mathrm{g} \mathrm{Cl}^{-1}\right)}$ & $53 \pm 12$ & $94 \pm 9$ & Olson \& Strom (2002) \\
\hline $\begin{array}{l}\text { Washington USA } \\
\text { continental shelf }\end{array}$ & $\begin{array}{c}\left.30 \pm 15 \mu g \mathrm{Cl}^{-1}\right) \\
(20-52)\end{array}$ & $54 \pm 12$ & $80 \pm 12$ & Olson et al. (2006) \\
\hline $\begin{array}{l}\text { Oregon USA } \\
\text { upwelling system }\end{array}$ & $6.4 \pm 2.3 \mu \mathrm{g} \mathrm{C} \mathrm{l}^{-1}$ & $54 \pm 24$ & $70 \pm 17$ & Authors' (unpubl. data) \\
\hline $\begin{array}{l}\text { Northern German } \\
\text { Wadden Sea, winter }\end{array}$ & $\begin{array}{c}1.2(0-6) \mu \mathrm{g} \mathrm{Cl}^{-1} \\
2.7(0-10) \mu \mathrm{g} \mathrm{Cl} \mathrm{l}^{-1}\end{array}$ & $\begin{array}{c}5 \\
<1\end{array}$ & $\begin{array}{c}40 \\
-\end{array}$ & Tillmann \& Hesse (1998) \\
\hline $\begin{array}{l}\text { Northern German } \\
\text { Wadden Sea, spring }\end{array}$ & $\begin{array}{r}18.1(0-66) \mu g \mathrm{Cl}^{-1} \\
5.2(0-22) \mu \mathrm{g} \mathrm{C} \mathrm{l}^{-1}\end{array}$ & $\begin{array}{l}83 \\
50\end{array}$ & $\begin{array}{l}75 \\
44\end{array}$ & Tillmann \& Hesse (1998) \\
\hline $\begin{array}{l}\text { Northern German } \\
\text { Wadden Sea, summer }\end{array}$ & $\begin{array}{l}4.1(0.1-17) \mu g \mathrm{Cl}^{-1} \\
12.8(0-52) \mu \mathrm{g} \mathrm{C} \mathrm{l}^{-1}\end{array}$ & $\begin{array}{l}69 \\
57\end{array}$ & $\begin{array}{l}20 \\
28\end{array}$ & Tillmann \& Hesse (1998) \\
\hline $\begin{array}{l}\text { Kattegat, Denmark, } \\
\text { April-October }\end{array}$ & $\begin{array}{c}430 \pm 230 \mathrm{mg} \mathrm{C} \mathrm{m} \mathrm{m}^{-2} \\
(190-780)\end{array}$ & $63 \pm 25$ & $64 \pm 32$ & Levinsen \& Nielsen (2002) \\
\hline $\begin{array}{l}\text { Open North Atlantic, } \\
\text { Spring and summer }\end{array}$ & $\stackrel{-}{\left(0.2-2.9 \mu \mathrm{C} \mathrm{C}^{-1}\right)}$ & $\begin{array}{c}50 \\
(24-64)\end{array}$ & - & Lessard \& Murrell (1996) \\
\hline $\begin{array}{l}\text { Gulf of Trieste, } \\
\text { February diatom bloom }\end{array}$ & $8.4 \mu \mathrm{g} \mathrm{C}^{-1}$ & 86 & - & Umani \& Beran (2003) \\
\hline $\begin{array}{l}\text { Gulf of Trieste, } \\
\text { non-bloom }\end{array}$ & $\begin{array}{c}6.0 \pm 0.8 \mu \mathrm{g} \mathrm{C} \mathrm{l}^{-1} \\
(5.4-6.9)\end{array}$ & $3 \pm 1$ & - & Umani \& Beran (2003) \\
\hline
\end{tabular}




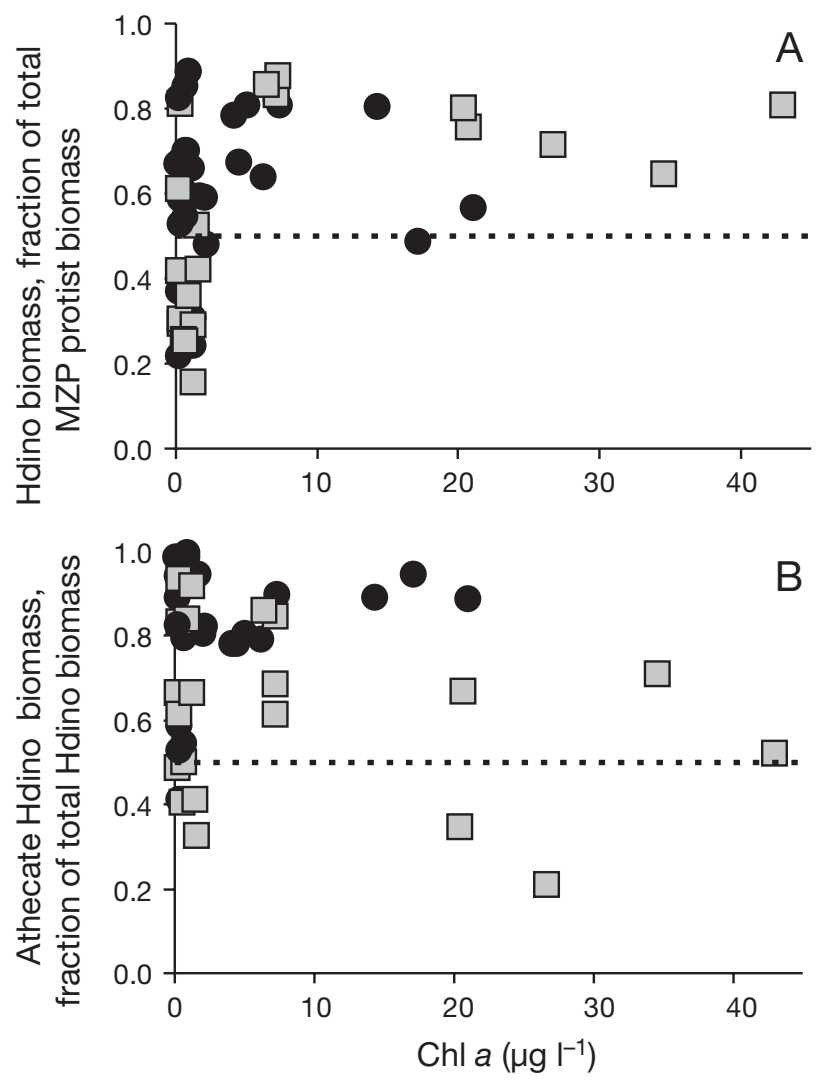

Fig. 1. Relationship between chl a concentration in samples collected in the Western Arctic Ocean (O) and in the California Current System off the coast of Oregon, USA ( $\square$ ) and (A) heterotrophic dinoflagellates (Hdino) biomass (as a fraction of total microzooplankton [MZP, Hdino + ciliate) biomass), and (B) athecate Hdino biomass (as a fraction of total Hdino biomass). Dashed lines represent a fractional value of 0.5 ; for values above the line in (A), Hdino biomass comprised $>50 \%$ of total MZP protist biomass, and in (B) athecate Hdino biomass comprised $>50 \%$ of total Hdino biomass. Data based on inverted microscopy of Lugol-preserved samples (Sherr et al. in press and authors' unpubl. data). Briefly, 50-100 $\mathrm{ml}$ of Lugol-preserved (5 or $10 \%$ final volume) sample was settled for a minimum of $24 \mathrm{~h}$ and the whole slide was inspected by inverted light microscopy. All ciliate and heterotrophic dinoflagellate cells in each sample were counted, measured, and categorized into general taxonomic groups. In each sample inspected 200 to 600 protist cells were counted and measured. Samples preserved for epifluorescence microscopy were inspected to determine whether dinoflagellates counted in Lugol-preserved samples were hetero- or autotrophic; Hdino morphotypes were included in the microzooplankton data. The biovolume of each enumerated cell was determined using algorithms for spherical, conical, and ellipsoidal shapes. Cell biomass was estimated from biovolume using the algorithm of Menden-Deuer \& Lessard (2000)

lates may compose only a small proportion of microzooplankton biomass (Table 1). The results also demonstrate that athecate heterotrophic dinoflagellates may account for a large fraction (up to $90 \%$ ) of the total biomass of heterotrophic dinoflagellates.
There is additional anecdotal evidence that heterotrophic dinoflagellates are often present under conditions of high chlorophyll a ( $\mathrm{chl}$ a) concentration, particularly during coastal diatom blooms, and that most of these dinoflagellates are gymnodinoid species (summarized in Table 2). In addition, in 2 recent studies in systems characterized by mass diatom blooms (the California Current System and the Western Arctic Ocean), we found that heterotrophic dinoflagellates composed from 20 to $>80 \%$ of total microzooplankton biomass across a range of trophic states (trophic status based on chl a concentration) with higher proportions of heterotrophic dinoflagellates at higher phytoplankton biomass (Fig. 1A). The contribution of athecate dinoflagellates to total heterotrophic dinoflagellate biomass in these 2 systems was variable, but was generally $>50 \%$ (Fig. 1B).

\section{Heterotrophic gymnodinoid dinoflagellates as major consumers of bloom-forming diatoms}

In microzooplankton communities of marine systems where diatom blooms occur, heterotrophic dinoflagellates tend to be abundant (Hansen 1991, Archer et al. 2000, Putland 2000, Olson \& Strom 2002, Verity et al. 2002, Horner et al. 2005, Leising et al. 2005a). Initial focus on the ability of thecate dinoflagellates to consume bloom-forming diatoms followed demonstrations in culture that thecate non-pigmented dinoflagellates (e.g. Protoperidinium spp. such as the cell shown in Fig. 2D) (Jacobson \& Anderson 1986, 1993, Buskey 1997), Oblea rotunda (Strom \& Buskey 1993) and Diplopsalis lenticula (Naustvoll 1998) can feed on large cells (such as chain-forming diatoms) using an extruded pseudopodial membrane or pallium. However, athecate heterotrophic dinoflagellates such as Gyrodinium sp. also feed by direct ingestion of both large single diatom cells and diatom chains (Hansen 1992, Neuer \& Cowles 1994, Li 1996, Strom \& Strom 1996, Putland 2000, Horner et al. 2005, Saito et al. 2006). Putland (2000) estimated that athecate heterotrophic dinoflagellates in Logy Bay, Newfoundland, could have accounted for 38 to $61 \%$ of total microzooplankton grazing impact on spring diatom blooms. Saito et al. (2006) reported that heterotrophic Gyrodinium sp. increased dramatically in abundance during an iron-

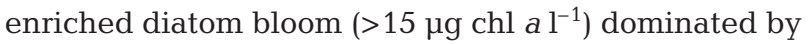
Chaetocerous debilis; the dinoflagellates fed on diatom chains up to 12 times their own length. A mathematical model based on observed rates of grazing by Gyrodinium sp. suggested that the heterotrophic dinoflagellates could have grazed down the diatom bloom to ambient abundance within 7 to $8 \mathrm{~d}$ (Saito et al. 2006). Failure to account for the athecate component of the 


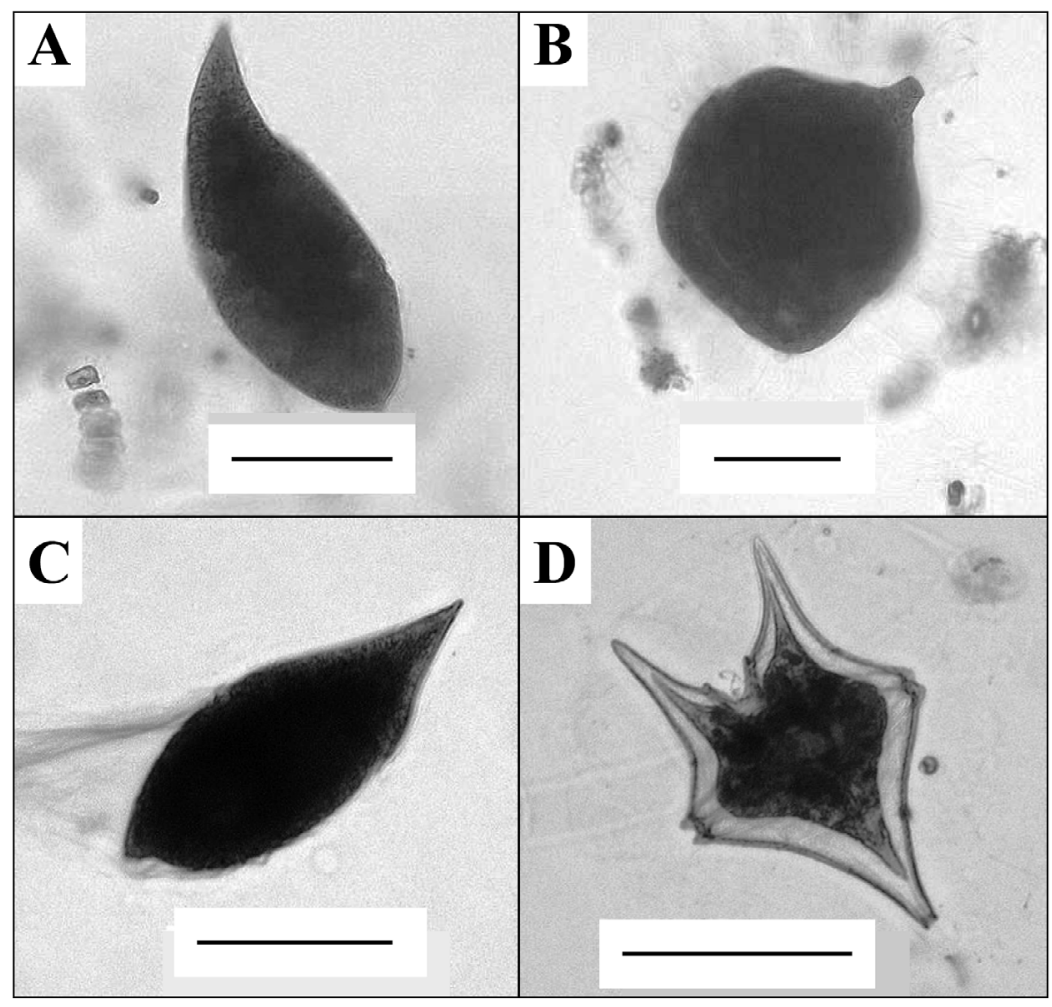

Fig. 2. Large dinoflagellate morphotypes (commonly associated with diatom blooms in the western Arctic Ocean and in the Oregon upwelling system) preserved with acid Lugol solution and visualized and measured using an image analysis system consisting of a Cooke Sensicam QE CCD camera with Image Pro Plus software, mated to an Olympus BX61 Microscope. (A) Arctic Ocean, spindleor fusiform-shaped gymnodinoid dinoflagellate with sharp cell apex, similar to Gyrodinium spirale; (B) Arctic Ocean, round gymnodinoid dinoflagellate with blunt cell apex; (C) Northeastern Pacific (Oregon upwelling), spindle- or fusiformshaped gymnodinoid dinoflagellate with sharp cell apex, similar to Gyrodinium spirale; (D) Northeastern Pacific (Oregon upwelling), thecate heterotrophic dinoflagellate, tentatively identified as a Protoperidinium sp. Scale bars $=50 \mu \mathrm{m}$

grazing on diatom blooms in Dabob Bay, Washington, USA, Leising et al. $(2005 a, b, c)$ found that microzooplankton (dominated by large gymnodinoid dinoflagellates) were the major grazers of diatoms and that copepod herbivory had much less impact on bloom diatoms. In fact, selective consumption of microzooplankton herbivores by copepods could relieve grazing pressure on diatoms.

\section{Heterotrophic gymnodinoid dinofla- gellates can consume and grow on a wide range of prey}

Several studies report feeding and growth rates of phagotrophic dinoflagellates, although most of these have been based on growth and grazing rates of cultured monospecific isolates. Gymnodinoid dinoflagellates have a wide range of prey types and sizes (e.g. Lessard 1991, Hansen 1992, Nakamura et al. 1995a, Jeong 1999). Small $(<20 \mu \mathrm{m})$ gymnodinoid dinoflagellates feed on coccoid cyanobacteria (Strom 1991) and on small (2-5 $\mu \mathrm{m})$ eukaryotic phytoplankton (Sherr et al. 1991). Larger species of gymnodinoid dinoflagellates feed and grow on a wide variety of prey types, including individual taxa of phytoflagellates and centric diatoms ranging in size from 7 to $50 \mu \mathrm{m}$ in equivalent spherical diameter (Hansen 1992), the

heterotrophic dinoflagellate community in estimates of microzooplankton biomass may lead to underestimation of the potential for dinoflagellates to consume large diatoms in a particular system.

Few studies compare potential dinoflagellate and copepod grazing pressures on diatoms. We have already mentioned the results of Landry et al. (2000), which shows that microzooplankton (including large sized heterotrophic dinoflagellates) rather than mesozooplankton were the dominant consumers of an ironenriched diatom bloom. Jeong et al. (2004) compared grazing impacts of thecate dinoflagellates (Protoperidinium bipes) and copepods (Acartia spp.) on blooms of the diatom Skeletonema costatum in Korean coastal waters; they estimated that at ambient abundances, the dinoflagellates could consume 0.1 to $3.4 \% \mathrm{~h}^{-1}$ of $S$. costatum biomass, while Acartia spp. could remove $<0.2 \% \mathrm{~h}^{-1}$. In a comprehensive study of red tide ochrophyte Chattonella antiqua (Nakamura et al. 1992), the red-tide dinoflagellates Prorocentrum minimum (Kim \& Jeong 2004) and Gymnodinium mikimotoi (Nakamura et al. 1995b), the harmful raphidophyte Heterosigma akashiwo (Jeong et al. 2005), diverse phytoflagellates (Nakamura et al. 1995a, Tang \& Simó 2003) and heterotrophic nanoflagellates (Jeong et al. 2007). This last report supports the observation of Lessard \& Rivkin (1986) that athecate heterotrophic dinoflagellates consume either bacterioplankton or bacterivores during early spring in Antarctic waters.

\section{Survival of dinoflagellates at low prey abundance}

Although some species of dinoflagellate are known to form cysts when food concentrations fall below a critical threshold (Goodman 1987), gymnodinoid 
Table 2. Reports of heterotrophic dinoflagellates, with emphasis on gymnodinoid dinoflagellates, in various oceanic regions

\begin{tabular}{|c|c|c|}
\hline Region & Comments & Source \\
\hline \multicolumn{3}{|l|}{ Polar } \\
\hline $\begin{array}{l}\text { Weddell Sea, } \\
\text { Southern Ocean }\end{array}$ & $\begin{array}{l}\text { Heterotrophic Gymnodinium sp. suggested to be important herbivores } \\
\text { in the Weddell Sea }\end{array}$ & Bjørnsen \& Kuparinen (1991) \\
\hline $\begin{array}{l}\text { East Antarctica, } \\
\text { Southern Ocean }\end{array}$ & Gyrodinium sp. abundant and important herbivore & Archer et al. (1996) \\
\hline Canadian Arctic & Heterotrophic Gyrodinium spp. observed to feed on diatoms & Bursa (1961) \\
\hline Disko Bay, Greenland & $\begin{array}{l}\text { Heterotrophic dinoflagellate biomass dominated by athecate species, } \\
\text { mainly gymnodinoids }\end{array}$ & $\begin{array}{l}\text { Nielsen \& Hansen (1995), } \\
\text { Levinsen \& Neilsen (2002) }\end{array}$ \\
\hline Disko Bay, Greenland & $\begin{array}{l}\text { During diatom blooms, heterotrophic dinoflagellates averaged } 70 \% \text { of } \\
\text { integrated microzooplankton biomass }\end{array}$ & Levinsen et al. (1999) \\
\hline Barents Sea & Heterotrophic dinoflagellates coincident with diatoms & Verity et al. (2002) \\
\hline Western Arctic Ocean & $\begin{array}{l}\text { Athecate heterotrophic dinoflagellates, including Gyrodinium spp, } \\
\text { composed } 20 \text { to } 88 \% \text { of total microzooplankton biomass, and were most } \\
\text { abundant during diatom blooms }\end{array}$ & Sherr et al. (in press) \\
\hline \multicolumn{3}{|l|}{ Sub-Arctic } \\
\hline $\begin{array}{l}\text { Subarctic Northwest } \\
\text { Pacific Ocean }\end{array}$ & $\begin{array}{l}\text { Large heterotrophic Gyrodinium spp. were major grazers of an iron- } \\
\text { enrichment-induced diatom bloom }\end{array}$ & Saito et al. (2006) \\
\hline Shelikof Strait, Alaska & $\begin{array}{l}\text { Heterotrophic dinoflagellates dominated the microprotozoan } \\
\text { assemblage during the spring diatom bloom }\end{array}$ & Howell-Kubler et al. (1996) \\
\hline Bering Sea & $\begin{array}{l}\text { Increase in biomass of Gyrodinium spp. paralleled increase in biomass } \\
\text { of large phytoplankton }\end{array}$ & Olson \& Strom (2002) \\
\hline $\begin{array}{l}\text { Southeastern Bering } \\
\text { Sea }\end{array}$ & $\begin{array}{l}\text { Heterotrophic dinoflagellates (Hdino) were greater contributors to } \\
\text { microzooplankton biomass than were ciliates (Cil), with an average } \\
\text { ratio of } 2.3 \text { Hdino:Cil }\end{array}$ & $\begin{array}{l}\text { S. Strom \& K. Fredrickson } \\
\text { (unpubl. data) }\end{array}$ \\
\hline Coastal Gulf of Alaska & $\begin{array}{l}\text { Gymnodinioid forms dominated the dinoflagellates; at stations with } \\
\text { diatom blooms, dinoflagellates were twice as abundant as ciliates }\end{array}$ & Liu et al. (2005) \\
\hline $\begin{array}{l}\text { Newfoundland coastal } \\
\text { waters }\end{array}$ & $\begin{array}{l}\text { Gymnodinium spp. composed ca. } 80 \% \text { of total dinoflagellates counted } \\
\text { during the spring diatom bloom }\end{array}$ & Putland (2000) \\
\hline \multicolumn{3}{|c|}{ Temperate coastal } \\
\hline Kattegat, Denmark & $\begin{array}{l}\text { Athecate heterotrophic dinoflagellates (including Gyrodinium spirale) } \\
\text { important herbivores in pelagic food webs }\end{array}$ & $\begin{array}{l}\text { Hansen }(1991,1992) \\
\text { Levinsen \& Neilsen (2002) }\end{array}$ \\
\hline $\begin{array}{l}\text { Northern German } \\
\text { Wadden Sea }\end{array}$ & $\begin{array}{l}\text { Athecate herotrophic dinoflagellates, such as Gymnodinium } \\
\text { heterosttiatum, fed on Phaeocystis cells }\end{array}$ & Tillmann \& Hesse (1998) \\
\hline $\begin{array}{l}\text { West coast } \\
\text { of Sweden }\end{array}$ & $\begin{array}{l}\text { Gyrodinium cf. spirale increased exponentially after the peak of the } \\
\text { spring bloom and was able to control further diatom growth }\end{array}$ & Tiselius \& Kuylenstierna (1996) \\
\hline $\begin{array}{l}\text { Narragansett Bay, } \\
\text { Rhode Island, USA }\end{array}$ & $\begin{array}{l}\text { A Gyrodinium sp. isolated from the Bay was found to consume diatoms } \\
\text { and grow in culture }\end{array}$ & Li (1996) \\
\hline $\begin{array}{l}\text { Harbor of Alexandria, } \\
\text { Egypt }\end{array}$ & $\begin{array}{l}>50 \mu \mathrm{m} \text { sized cells (including Gyrodinium fusiforme) contributed }>90 \% \\
\text { of the biomass of heterotrophic dinoflagellates }\end{array}$ & Ismael (2003) \\
\hline $\begin{array}{l}\text { Gulf of Trieste, } \\
\text { Northern Adriatic Sea }\end{array}$ & $\begin{array}{l}\text { Gyrodinium spp. dominated the community of heterotrophic } \\
\text { dinoflagellates from November to May }\end{array}$ & Umani \& Beran (2003) \\
\hline Korean coastal waters & $\begin{array}{l}\text { Gyrodinium dominans and G. spirale consumed a red-tide } \\
\text { dinoflagellate and grew }\end{array}$ & Kim \& Jeong (2004) \\
\hline $\begin{array}{l}\text { Dabob Bay, Puget } \\
\text { Sound, Washington }\end{array}$ & $\begin{array}{l}\text { Gyrodinium spirale was a major contributor to microplankton carbon } \\
\text { and consumed diatoms }\end{array}$ & Horner et al. (2005) \\
\hline $\begin{array}{l}\text { Coastal Pacific Ocean } \\
\text { off Washington }\end{array}$ & $\begin{array}{l}80 \% \text { of heterotrophic dinoflagellate biomass was composed of athecate } \\
\text { species; highest clearance rates by Calanus pacificus were on } \\
\text { heterotrophic gymnodinoid dinoflagellates }\end{array}$ & Olson et al. (2006) \\
\hline $\begin{array}{l}\text { Oregon upwelling } \\
\text { system }\end{array}$ & $\begin{array}{l}\text { Gyrnnodinoid dinoflagellates were most abundant during the upwelling } \\
\text { season, often exceeding the biovolume of choreotrich ciliates and of } \\
\text { thecate dinoflagellates. Rates of herbivory were closely linked to the } \\
\text { abundance of this group of dinoflagellates. The abundance of large-celled } \\
\text { gymnodinoids }(>20 \mu \mathrm{m}) \text { and large phytoplankton }(>20 \mu \mathrm{m} \text {, mostly diatoms) } \\
\text { covaried, indicating that the bloom-forming diatoms were being utilized } \\
\text { as a food source }\end{array}$ & 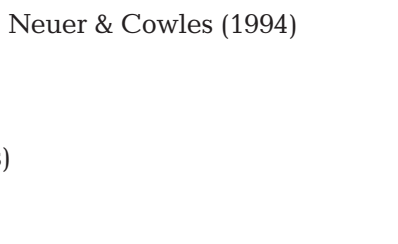 \\
\hline
\end{tabular}


Table 2 (continued)

\begin{tabular}{|c|c|c|}
\hline Region & Comments & Source \\
\hline $\begin{array}{l}\text { Mejillones Bay Chile } \\
\text { upwelling system }\end{array}$ & $\begin{array}{l}\text { Heterotrophic dinoflagellates were the major grazers of large diatoms, } \\
\text { and were a food resource for copepods }\end{array}$ & Vargas \& Gonzalez (2004) \\
\hline \multicolumn{3}{|c|}{ Temperate/subtropical open ocean } \\
\hline North Atlantic Ocean & $50 \%$ of dinoflagellate species were heterotrophic & Lessard \& Swift (1986) \\
\hline North Atlantic Ocean & $\begin{array}{l}\text { Spindle-shaped heterotrophic Gyrodinium sp. } 10-15 \mu \mathrm{m} \text { in } \\
\text { length were abundant and grazed }<5 \mu \mathrm{m} \text { phytoplankton }\end{array}$ & Verity et al. (1993) \\
\hline Gulf of Mexico & $\begin{array}{l}\text { Gyrodinium spp. were an important component of the microzooplankton } \\
\text { and were observed to ingest chain-forming diatoms }\end{array}$ & Strom \& Strom 1996) \\
\hline $\begin{array}{l}\text { Eastern equatorial } \\
\text { Pacific IronEx II }\end{array}$ & $\begin{array}{l}\text { Grazing impact of larger protists, dinoflagellates and ciliates }>20 \mu \mathrm{m} \text { in } \\
\text { size, was especially apparent at the peak of the iron induced patch bloom } \\
\text { of large pennate diatoms, when a balance between growth and grazing } \\
\text { appears to have been achieved }\end{array}$ & Landry et al. (2000) \\
\hline $\begin{array}{l}\text { Bay of Bengal and } \\
\text { the Andaman Sea }\end{array}$ & $\begin{array}{l}\text { Heterotrophic dinoflagellates averaged } 59 \% \text {, and were as high as } 80 \% \text {, } \\
\text { of total microzooplankton biomass }\end{array}$ & Jyothibabu et al. (2003) \\
\hline Indian Ocean & $\begin{array}{l}\text { The dinoflagellate community was dominated by athecate species, } \\
\text { e.g. Gyrodinium spirale, G. dominans, G. glaucum }\end{array}$ & Nielsen et al. (2004) \\
\hline
\end{tabular}

dinoflagellates isolated from marine pelagic habitats do not encyst in culture (Hansen 1992). Heterotrophic dinoflagellates may adapt to low prey abundance by reducing metabolic rate when they have stopped growing. Reduction in the rate of respiration in starving protists (in comparison with actively growing cells) has been demonstrated in a number of laboratory experiments with isolated species (Fenchel \& Finlay 1983). Both thecate and athecate species of heterotrophic dinoflagellates persist in the absence of prey. Survival of the thecate dinoflagellate Protoperidinium

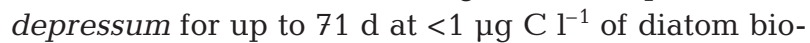
mass was likely due to a reduction in the dinoflagellate's metabolic rate (Menden-Deuer et al. 2005). Hansen (1992) found that when moderately starved cells of Gyrodinium spirale were completely deprived of prey, they persisted for $48 \mathrm{~h}$ with minimal decrease in abundance. Jakobsen \& Hansen (1997) reported that under starvation conditions, the heterotrophic dinoflagellate Gymnodinium sp. survived for a longer time than the ciliate Balanion comatum. At high densities in laboratory culture $\left(10^{3}\right.$ to $10^{4}$ cells $\left.\mathrm{ml}^{-1}\right)$, phagotrophic dinoflagellates may resort to cannibalism when biomass of other prey is low (e.g. Jeong \& Latz 1994); however, at the low cell abundances of heterotrophic dinoflagellates in situ $\left(<1\right.$ to $\left.100 \mathrm{ml}^{-1}\right)$, it is less likely that cannibalism plays a role in survival.

\section{Other roles of heterotrophic dinoflagellates in marine pelagic systems}

In addition to their role as herbivores in marine systems, ciliates and heterotrophic dinoflagellates in the microzooplankton serve as a quantitatively and qualitatively significant food resource for mesozooplankton (Stoecker \& Capuzzo 1990, Kleppel 1993, Suzuki et al. 1999, Levinsen et al. 2000, Vincent \& Hartmann 2001, Leising et al. 2005b,c, Liu et al. 2005, Olson et al. 2006, Campbell et al. in press). Due to their cell size and biochemical composition, microzooplanktonic protists are often preferred food for copepods, and feeding on microzooplankton along with phytoplankton can enhance copepod fecundity (Kleppel 1993, Klein Breteler et al. 1999, Bonnet \& Carlotti 2001, Castellani et al. 2005).

Athecate heterotrophic dinoflagellates have been indentified as a significant food resource for mesozooplankton (Stoecker \& Capuzzo 1990, Suzuki et al. 1999, Levinsen et al. 2000, Vincent \& Hartmann 2001, Leising et al. 2005b,c, Liu et al. 2005, Olson et al. 2006). Suzuki et al. (1999) found that heterotrophic gymnodinoid dinoflagellates were cleared by Paracalanus sp. at much higher rates than ciliates in the Seto Inland Sea, Japan. During diatom blooms in the Gulf of Alaska, heterotrophic dinoflagellates were a more important component of the diet of the copepod Neocalanus cristatus than were ciliates (Liu et al. 2005). Leising et al. $(2005 b, c)$ reported that large gymnodinoid dinoflagellates formed a variable but often important component of the diet of copepods in Dabob Bay, Washington, and Olson et al. (2006) found that heterotrophic gymnodinoid dinoflagellates were preferred prey for copepods off the coast of Washington state, USA.

Consumption of diatoms by heterotrophic dinoflagellates (both thecate and athecate species) also has implications for biogeochemical cycles. In the process of feeding on diatoms, pallium-feeding thecate 
dinoflagellates discard empty silica frustules (Jacobsen \& Anderson 1986), while athecate dinoflagellates that directly ingest diatoms produce mini-fecal pellets composed of frustules with little associated carbon (Buck \& Newton 1995, Strom \& Strom 1996, Horner et al. 2005, Saito et al. 2006). The production of these pellets uncouples the sinking flux of diatom silica and carbon, speeding up the dissolution rate of frustules. In addition, heterotrophic dinoflagellate grazing contributes to recycling of inorganic nitrogen and phosphorus via excretion of dissolved and particulate materials, in addition to the nutrient regeneration due to heterotrophic bacteria, bacterivorous flagellates, other herbivorous protists, and metazoans (Caron \& Goldman 1990, Dolan 1997, Kirchman 2000).

\section{CONCLUSIONS}

Based on the observations summarized above, we propose that herbivorous dinoflagellates, especially athecate gymnodinoid forms, are the component of the microzooplankton with the greatest impact on bloomforming diatoms. Ciliates have not been shown to effectively feed on large or chain-forming diatoms, and thecate dinoflagellates such as Protoperidinium spp., in general, are less abundant than athecate dinoflagellates during diatom blooms. In addition, the broad prey spectrum of gymnodinoid dinoflagellates and their ability to persist under conditions of low prey abundance suggest that these protists may be able to survive under a wide range of conditions in the sea, and thus be positioned to quickly increase to high abundance during diatom blooms (as observed by Saito et al. (2006) during an iron-enrichment-induced bloom).

Failure to accurately conceptualize the major trophic pathways of marine food webs has implications for the success of future research programs and modeling efforts. If heterotrophic dinoflagellates are not included in analyses of microzooplankton, plankton food web models incorporating microzooplankton growth and grazing scaled to field-measured biomass stocks would seriously underestimate this (the microzooplankton) component of the plankton community. In many previous studies of microzooplankton herbivory, ciliates were the only grazing protists enumerated (Dolan \& McKeon 2004).

One reason for the failure to include dinoflagellates in assessments of microzooplankton communities is that the 'gold standard' for preservation and enumeration of large protists, i.e. acid Lugol fixation followed by inverted microscopy (Utermöhl 1931), precludes identification of chloroplasts in protistan cells. Thus, it is not easy to distinguish strictly heterotrophic from autotrophic dinoflagellates using this approach. Epi- fluorescence microscopy allows discrimination of these types of dinoflagellates. However, in our experience, heterotrophic dinoflagellates are not adequately enumerated by settlement on filters, due to lysis of a variable fraction of athecate forms during aldehyde preservation and filtration. One approach to dealing with this problem is preparation and inspection of paired subsamples, one preserved with 5 to $10 \%$ final concentration acid Lugol's solution, and the other preserved with aldehyde fixative, stained with a fluorochrome such as DAPI, settled onto membrane filters and stored frozen until inspection via epifluorescence microscopy (Sherr \& Sherr 1993). In this way, quantitative counts can be made via the Utermöhl method, and morphological types of dinoflagellates that are observed in a Lugolpreserved sample can be checked for presence or absence of chloroplasts in a corresponding sample prepared for epifluoresence microscopy.

It is clear that the contribution of dinoflagellates to the stocks and rate processes of microzooplankton can no longer be discounted in studies of the structure and functioning of marine pelagic food webs. We urge that in future research efforts, stocks and grazing impacts of phagotrophic dinoflagellates (including thecate and athecate species) be assessed, and that conceptual and simulation models of pelagic food webs explicitly include the potentially major trophic link between these protists and bloom-forming diatoms.

Acknowledgements. Funding for assessment of microzooplankton stocks in the California Current System was provided by NSF grant OCE-0101204 to B.S. and E.S., and in the Western Arctic Ocean by NSF grant OPP-0124892 to B.S. and E.S.

\section{LITERATURE CITED}

Archer SD, Leakey RJG, Burkill PH, Sleigh MA (1996) Microbial dynamics in coastal waters of east Antarctica: herbivory by heterotrophic dinoflagellates. Mar Ecol Prog Ser 139:239-255

Archer SD, Verity PG, Stefels J (2000) Impact of microzooplankton on the progression and fate of the spring bloom in fjords of northern Norway. Aquat Microb Ecol 22:27-41

Barber RT, Hiscock MR (2006) A rising tide lifts all phytoplankton: growth response of other phytoplankton taxa in diatom-induced blooms. Global Biogeochem Cycles 20: GB4s03, doi:1029/2006GB002726

Bjørnsen PK, Kuparinen J (1991) Growth and herbivory by heterotrophic dinoflagellates in the Southern Ocean, studied by microcosm experiments. Mar Biol 109:397-405

Bockstahler KR, Coats DW (1993) Grazing of the mixotrophic dinoflagellate Gymnodinium sanguineum on ciliate populations of Chesapeake Bay. Mar Biol 116:477-487

Bonnet D, Carlotti F (2001) Development and egg production in Centropages typicus (Copepoda: Calanoida) fed different food types: a laboratory study. Mar Ecol Prog Ser 224: 133-148

Buck KR, Newton J (1995) Fecal pellet flux in Dabob Bay during a diatom bloom: contribution of microzooplankton. Limnol Oceanogr 40:306-315 
Bursa AS (1961) The annual oceanographic cycle at Igloolik in the Canadian Arctic. II. The phytoplankton. J Fish Res Board Can 18:563-615

Buskey EJ (1997) Behavioral components of feeding selectivity of the heterotrophic dinoflagellate Protoperidinium pellucidum. Mar Ecol Prog Ser 153:77-89

Calbet A, Landry MR (2004) Phytoplankton growth, microzooplankton grazing, and carbon cycling in marine systems. Limnol Oceanogr 40:51-57

Campbell R, Sherr E, Ashjian C, Plourde S, Sherr B, Hill V, Stockwell D (in press) Mesozooplankton prey preference and grazing impact in the Western Arctic Ocean. DeepSea Res II

Caron DA, Goldman JC (1990) Protozoan nutrient regeneration. In: Capriulo GM (ed) Ecology of marine protozoa. Oxford University Press, New York, p 283-306

Castellani C, Irigoien X, Harris R, Lampitt R (2005) Feeding and egg production of Oithona similis in the North Atlantic. Mar Ecol Prog Ser 228:173-182

Dolan JR (1997) Phosphorus and ammonia excretion by planktonic protists. Mar Geol 139:109-122

Dolan JR, McKeon K (2004) The reliability of grazing rate estimates from dilution experiments: have we over-estimated rates of organic carbon consumption? Ocean Sci Discussions 1:21-36

Dolan JR, Gallegos CL, Moigis A (2000) Dilution effects on microzooplankton in dilution grazing experiments. Mar Ecol Prog Ser 200:127-139

Ducklow HW (1983) Production and fate of bacteria in the oceans. BioScience 33:494-501

Fenchel T (1987) Ecology of protozoa: the biology of free living phagotrophic protists. Science Tech Publications, Madison, WI

Fenchel T, Finlay BJ (1983) Respiration rates in heterotrophic, free-living protozoa. Microb Ecol 9:99-122

Goodman DK (1987) Dinoflagellate cysts in ancient and modern sediments. In: Taylor FJR (ed) The biology of dinoflagellates. Blackwell, Oxford, p 649-722

Hansen PJ (1991) Quantitative importance and trophic role of heteotrophic dinoflagellates in a coastal pelagic food web. Mar Ecol Prog Ser 73:253-261

Hansen PJ (1992) Particle size selection, feeding rates and growth dynamics of marine heterotrophic dinoflagellates, with special emphasis on Gyrodinium spirale. Mar Biol 114: 327-334

Hansen PJ, Calado AJ (1999) Phagotrophic mechanisms and prey selection in free living dinoflagellates. J Eukaryot Microbiol 46:382-389

Horner RA, Postel JR, Halsband-Lenk C, Pierson JJ, Pohnert G, Wichard T (2005) Winter-spring phytoplankton blooms in Dabob Bay, Washington. Prog Oceanogr 67:286-313

Howell-Kubler AN, Lessard EJ, Napp JM (1996) Springtime microprotozoan abundance and biomass in the southeastern Bering Sea and Shelikof Strait, Alaska. J Plankton Res 18:731-745

Ismael AA (2003) Succession of heterotrophic and mixotrophic dinoflagellates as well as autotrophic microplankton in the harbour of Alexandria, Egypt. J Plankton Res 25: 193-202

Jacobson DM, Anderson DM (1986) Thecate heterotrophic dinoflagellates: feeding behavior and mechanisms. J Phycol 22:249-258

Jacobson DM, Anderson DM (1993) Growth and grazing rates of Protoperdinium hirobis Abe, a thecate heterotrophic dinoflagellate. J Plankton Res 15:723-736

Jakobsen HH, Hansen PJ (1997) Prey size selection, grazing and growth response of the small heterotrophic dinoflagel- late Gymnodinium sp. and the ciliate Balanion comatuma comparative study. Mar Ecol Prog Ser 158:75-86

Jeong HJ (1999) The ecological roles of heterotrophic dinoflagellates in marine planktonic community. J Eukaryot Microbiol 46:390-396

Jeong HJ, Latz MI (1994) Growth and grazing rates of the heterotrophic dinoflagellate Protoperidinium spp. on red tide dinoflagellates. Mar Ecol Prog Ser 106:173-185

Jeong HJ, Shim JH, Kim JS, Park JY, Lee CW, Lee Y (1999) The feeding by the thecate mixotrophic dinoflagellate Fragilidium cf. mexicanum on red tide and toxic dinoflagellates. Mar Ecol Prog Ser 176:263-277

Jeong HJ, Yoo YD, Kim ST, Kang NS (2004) Feeding by the heterotrophic dinoflagellate Protoperidinium bipes on the diatom Skeletonema costatum. Aquat Microb Ecol 36: 171-179

Jeong HJ, Kim JS, Kim JH, Kim ST, Seong KA, Kim TH, Song JY, Kim SK (2005). Feeding and grazing impact by the newly described heterotrophic dinoflagellate Stoeckeria algicida on the harmful alga Heterosigma akashiwo. Mar Ecol Prog Ser 295:69-78

Jeong, HJ, Song, JE, Kang, NS, Kim S, Yoo YD, Park JY (2007) Feeding by heterotrophic dinoflagellates on marine heterotrophic nanoflagellates. Mar Ecol Prog Ser 333:151-160

Jonnson PR (1986) Particle size selection, feeding rates and growth dynamics of marine heterotrophic planktonic oligotrichous ciliates. Mar Ecol Prog Ser 33:568-572

Jyothibabu R, Madhu NV, Maheswaran PA, Nair KKC, Venugopal P, Balasubramanian T (2003) Dominance of dinoflagellates in microzooplankton community in the oceanic regions of the Bay of Bengal and the Andaman Sea. Curr Sci 84:1247-1253

Kim JS, Jeong HJ (2004) Feeding by the heterotrophic dinoflagellates Gyrodinium cf. guttula and G. spirale on the red-tide dinoflagellate Prorocentrum minimum. Mar Ecol Prog Ser 280:85-94

Kirchman DL (2000) Uptake and regeneration of inorganic nutrients by marine heterotrophic bacteria. In: Kirchman D (ed) Microbial ecology of the oceans. Wiley-Liss, New York, p 261-288

Klein-Breteler WCM, Schogt N, Bass M, Shouten S, Kraay GW (1999) Trophic upgrading of food quality by protozoans enhancing copepod growth: role of essential lipids. Mar Biol 135:191-198

Kleppel GS (1993) On the diets of calanoid copepods. Mar Ecol Prog Ser 99:183-195

Landry MR, Hasset RP (1982) Estimating the grazing impact of marine microzooplankton. Mar Biol 67:283-288

Landry MR, Kirshtein J, Constantinou J (1995) A refined dilution technique for measuring the community grazing impact of microzooplankton with experimental tests in the central equatorial Pacific. Mar Ecol Prog Ser 120:53-63

Landry MR, Ondrusek ME, Tanner SJ, Brown SL, Constantinou J, Bidigare RR, Coale KH, Fitzwater S (2000) Biological response to iron fertilization in the eastern equatorial Pacific (IronEx II). I. Microplankton community abundances and biomass. Mar Ecol Prog Ser 201:27-42

Leising AW, Horner RA, Pierson JJ, Postel JR, HalsbandLenk C (2005a) The balance between microzooplankton grazing and phytoplankton growth in a highly productive estuarine fjord. Prog Oceanogr 67:366-683

Leising AW, Pierson JJ, Halsband-Lenk C, Horner RA, Postel JR (2005b) Copepod grazing during spring blooms: does Calanus pacificus avoid harmful diatoms? Prog Oceanogr 67:384-405

Leising AW, Pierson JJ, Halsband-Lenk C, Horner RA, Postel JR (2005c) Copepod grazing during spring blooms: 
can Pseudocalanus newmani induce trophic cascades? Prog Oceanogr 67:406-421

Lessard EJ (1991) The trophic role of heterotrophic dinoflagellates in diverse marine environments. Mar Microb Food Webs 5:49-58

Lessard EJ, Murrell MC (1996) Distribution, abundance and size composition of heterotrophic dinoflagellates and ciliates in the subtropical Sargasso Sea. Deep-Sea Res I 43: 1045-1065

Lessard EJ, Rivkin RB (1986) Nutrition of microzooplankton and macrozooplankton from McMurdo Sound. Antarct J US 21:187-188

Lessard EJ, Swift E (1985) Species-specific grazing rates of heterotrophic dinoflagellates in oceanic waters, measured with a dual-label radioisotope technique. Mar Biol 87: 289-296

Lessard EJ, Swift E (1986) Dinoflagellates from the North Atlantic classified as phototrophic or heterotrophic by epifluorescence microscopy. J Plankton Res 8:1209-1215

Levinsen H, Nielsen TG (2002) The trophic role of marine pelagic ciliates and heterotrophic dinoflagellates in arctic and temperate coastal ecosystems: a cross-latitude comparison. Limnol Oceanogr 47:427-439

Levinsen H, Nielsen TG, Hansen BW (1999) Plankton community structure and carbon cycling on the western coast of Greenland during the stratified summer situation. II. Heterotrophic dinoflagellates and ciliates. Aquat Microb Ecol 16:217-232

Levinsen H, Turner JT, Nielsen TG, Hansen BW (2000) On the trophic coupling between protists and copepods in arctic marine ecosystems. Mar Ecol Prog Ser 204:65-77

Li Y (1996) Growth, grazing and bioluminescence of marine heterotrophic dinoflagellates. PhD dissertation, University of Rhode Island, Providence, RI

Liu H, Dagg MJ, Strom S (2005) Grazing by the calanoid copepod Neocalanus cristatus on the microbial foodweb in the coastal Gulf of Alaska. J Plankton Res 27:647-662

Maixandeau A, Lefevre D, Krayanni H and 7 others (2005) Microbial community production, respiration, and structure of the microbial food web of an ecosystem in the northeastern Atlantic Ocean. J Geophys Res 110:C07S17, doi: 10.1029/2004JC002694

Menden-Deuer S, Lessard E (2000) Carbon to volume relationships for dinoflagellates, diatoms, and other protist plankton. Limnol Oceanogr 45:569-579

Menden-Deuer S, Lessard EJ, Satterberg J, Grünbaum D (2005) Growth rates and starvation survival of the pallium-feeding, thecate dinoflagellate genus Peridinium. Aquat Microb Ecol 41:145-152

Nakamura Y, Yamakazi Y, Hiromi J (1992) Growth and grazing of a heterotrophic dinoflagellate, Gyrodinium dominans, feeding on a red-tide flagellate, Chattonella antiqua. Mar Ecol Prog Ser 82:275-279

Nakamura Y, Suzuki S, Hiromi J (1995a) Growth and grazing of a naked heterotrophic dinoflagellate, Gyrodinium dominans. Aquat Microb Ecol 9:157-164

Nakamura Y, Suzuki S, Hiromi, J (1995b) Population dynamics of heterotrophic dinoflagellates during a Gymnodinium mikimotoi red tide in the Seto Inland Sea. Mar Ecol Prog Ser 125:269-277

Naustvoll LJ (1998) Growth and grazing by the thecate heterotrophic dinoflagellate Diplopsalis lenticula (Diplopsalidaceae, Dinophyceae). Phycologia 37:1-9

Neuer S, Cowles TJ (1994) Protist herbivory in the Oregon upwelling system. Mar Ecol Prog Ser 113:147-162

Nielsen TG, Hansen N (1995) Plankton community structure and carbon cycling in the western coast of Greenland during and after the sedimentation of a diatom bloom. Mar Ecol Prog Ser 125:239-257

Nielsen TG, Bjørnsen PK, Boonruang P, Fryd M and 9 others (2004). Hydrography, bacteria and protist communities across the continental shelf and shelf slope of the Andaman Sea (NE Indian Ocean). Mar Ecol Prog Ser 274: $69-86$

Olson MB, Strom SL (2002) Phytoplankton growth, microzooplankton herbivory and community structure in the southeast Bering Sea: insight into the formation and temporal persistence of an Emiliania huxleyi bloom. Deep-Sea Res II 49:5969-5990

Olson MB, Lessard EJ, Wong CHJ, Berhhardt MJ (2006) Copepod feeding selectivity strongly influences the population ecology of the microplankton, including the toxigenic diatom, Pseudo-nitzschia spp., in the coastal Pacific Northwest. Mar Ecol Prog Ser 326:207-220

Passow U (1991) Species-specific sedimentation and sinking velocities of diatoms. Mar Biol 108:449-455

Perez MT, Dolan JR, Vidussi F, Fukai E (2000) Diel vertical distribution of planktonic ciliates within the surface layer of the NW Mediterranean (May 1995). Deep-Sea Res I 47: 479-503

Pierce RW, Turner JT (1995) Ecology of planktonic ciliates in marine food webs. Rev Aquat Sci 6:139-181

Putland JN (2000) Microzooplankton herbivory and bacterivory in Newfoundland coastal waters during spring, summer, and winter. J Plankton Res. 22:253-277

Rothstein LM, Cullent JJ, Abbott M, Chassignet E and others (2006) Modeling ocean ecosystems. Oceanography 19: $16-45$

Saito H, Ota T, Suzuki K, Nishioka J, Tsuda A (2006) Role of heterotrophic dinoflagellate Gyrodinium sp. in the fate of an iron induced diatom bloom. Geophys Res Lett 33: L09602, doi:10.1029/2005GL025366

Sarthou GK, Timmermans RS, Blain S, Treguer P (2005) Growth physiology and fate of diatoms in the ocean: a review. J Sea Res 53:25-42

Sherr EB, Sherr BF (1988) Role of microbes in pelagic food webs: a revised concept. Limnol Oceanogr 33:1225-1227

Sherr EB, Sherr BF (1992) Trophic roles of pelagic protists: phagotrophic flagellates as herbivores. Arch Hydrobiol Beih Ergebn Limnol 37:165-172

Sherr EB, Sherr BF (1993) Preservation and storage of samples for enumeration of heterotrophic protists. In: Kemp P, Sherr B, Sherr E, Cole J (eds) Current methods in aquatic microbial ecology. Lewis Publishers, Boca Raton, FL, p 207-212

Sherr EB, Sherr BF (2002) Significance of predation by protists in aquatic microbial food webs. Antonie Leewenhoek Int J Gen Mol Microbiol 81:293-308

Sherr EB, Sherr BF, McDaniel J (1991) Clearance rates of $<6 \mu \mathrm{m}$ fluorescently labeled algae (FLA) by estuarine protozoa: potential grazing impact of flagellates and ciliates. Mar Ecol Prog Ser 69:81-92

Sherr EB, Sherr BF, Hartz AJ (in press) Microzooplankton grazing impact in the Western Arctic Ocean. Deep-Sea Res II

Smetacek VS (1985) Role of sinking in diatom life-history cycles: ecological, evolutionary and geological significance. Mar Biol 84:239-251

Stoecker DK, Capuzzo JM (1990) Predation on protozoa: its importance to zooplankton. J Plankton Res 12:891-908

Strom SL (1991) Growth and grazing rates of an herbivorous dinoflagellate (Gymnodinium sp.) from the open subarctic Pacific Ocean. Mar Ecol Prog Ser 78:103-113

Strom SL, Buskey EJ (1993) Feeding, growth, and behavior of 
the thecate heterotrophic dinoflagellate Oblea rotunda. Limnol Oceanogr 38:965-977

Strom SL, Strom MW (1996) Microzooplankton growth, grazing and community structure in the northern Gulf of Mexico. Mar Ecol Prog Ser 130:229-240

Suzuki K, Nakamura Y, Hiromi J (1999) Feeding by the small calanoid copepod Paracalanus sp. on heterotrophic dinoflagellates and ciliates. Aquat Microb Ecol 17:99-103

Tang KW, Simó R (2003) Trophic uptake and transfer of DMSP in simple planktonic food chains. Aquat Microb Ecol 31: 193-202

Tillmann U, Hesse KJ (1998) On the quantitative importance of heterotrophic microplankton in the northern German Wadden Sea. Estuaries 21:585-596

Tiselius P, Kuylenstierna M (1996) Growth and decline of a diatom spring bloom: phytoplankton species composition, formation of marine snow and the role of heterotrophic dinoflagellates. J Plankton Res 18:133-150

Turner JT (2002) Zooplankton fecal pellets, marine snow and sinking phytoplankton blooms. Aquat Microb Ecol 27: $57-102$

Uchida T, Kamiyama T, Matsuyama Y (1997) Predation by a photosynthetic dinoflagellate Gyrodinium instriatum on loricated ciliates. J Plankton Res 19:603-608

Umani SF, Beran A (2003) Seasonal variations in the dynamics

Editorial responsibility: Otto Kinne (Editor-in-Chief), Oldendorf/Luhe, Germany of microbial plankton communities: first estimates from experiments in the Gulf of Trieste, northern Adriatic Sea. Mar Ecol Prog Ser 447:1-16

Utermöhl von H (1931) Neue Wege in der quantitativan Erfassung des Planktons (Mit besondere Berücksichtigung des Ultraplanktons). Verh Int Verein Theor Angew Limnol 5: 567-595

Vargas CA, Gonzalez HE (2004) Plankton community structure and carbon cycling in a coastal upwelling system. II. Microheterotrophic pathway. Mar Ecol Prog Ser 34:165-180

Verity PG, Stoecker D, Sieracki E, Burkill PH, Edwards ES, Tronzo CR (1993) Abundance, biomass and distribution of heterotrophic dinoflagellates during the North Atlantic spring bloom. Deep-Sea Res 40:227-244

Verity P, Wassmann P, Frischer ME, Howard-Jones MH, Allen AE (2002) Grazing of phytoplankton by microzooplankton in the Barents Sea during early summer. J Mar Syst 38: 109-123

Vincent D, Hartmann HJ (2001) Contribution of ciliated microprotozoans and dinoflagellates to the diet of three copepod species in the Bay of Biscay. Hydrobiologia 443:193-200

Vladstein O, Stibor H, Lippert B, Loseth K, Roederer W, Sundt-Hansen L, Olsen Y (2004) Moderate increase in the biomass of omnivorous copepods may ease grazing control of planktonic algae. Mar Ecol Prog Ser 270:199-207

Submitted: April 2, 2007; Accepted: July 13, 2007 Proofs received from author(s): November 27, 2007 